\title{
Learning from Ground Zero: The Presence of Absence at Two Sites of Destruction
}

\author{
Helaine Silverman
}

\begin{abstract}
The destroyed Bamiyan Buddhas in Afghanistan and the destroyed World Trade Center in New York City prompted almost immediate discussion and controversy over whether to reconstruct these structures and thereby fill the void on their respective landscapes. Despite the difference in their contexts, the two sites of destruction implicate a number of similar issues, including: respect for or mitigation of the void; pre and post destruction narratives about the sites; the concept of loss; inscription and erasure of memory on a lived, monumental landscape; the concept of heritage applied to the site; perceptions of value; the politics and ethics of decisionmaking concerning the impacted terrain; assertions, contestations, and goals of stakeholdership; the aesthetics of reconstruction; the symbolism of reconstruction; the emotional and affective dimensions of reconstruction; economic development after destruction and its intended beneficiaries; what is considered recovery and by whom; the future that reconstruction is anticipated to generate; and formal interpretive scripts about the destruction and the physical form these scripts take. This paper considers the difficulty of achieving a built solution for these voids, focusing on the people living close to the sites who were most directly affected by the destruction.
\end{abstract}

Keywords Ground Zero $\cdot$ Stakeholders $\cdot$ Memory $\cdot$ Discourse $\cdot$ Dissonance $\cdot$ Contested heritage $\cdot$ Bamiyan

In March 2001 the Taliban dynamited the ancient, towering Buddhas carved into a cliff face in the Bamiyan Valley, Afghanistan. Six months later, Al Qaeda terrorists destroyed the skyline-dominating twin towers of the World Trade Center (WTC) in

Published jointly by the United Nations Educational, Scientific and Cultural Organization (UNESCO), 7, place de Fontenoy, 75007 Paris, France, the UNESCO Office in Kabul, ICON Compound, Supreme Road, Off Jalalabad Road, PD 9, Kabul, Afghanistan, and Springer Nature Switzerland AG, Gewerbestrasse 1, 6330 Cham, Switzerland.

H. Silverman $(\bowtie)$

Department of Anthropology, University of Illinois at Urbana-Champaign,

Champaign, IL, USA

e-mail: helaine@illinois.edu 
New York City, USA. Both landmarks were emblematic of their landscape - one rural, the other urban. The former, a testament to a world once linked by a vast overland network of commerce and communication. The other, a cognate testament to an even vaster network. Both attacks had global significance: a religiously driven, symbolic attack in remote Bamiyan that challenged one kind of world order (the "international community," for instance as exemplified by UNESCO) and a political attack on the American financial capital that struck at the world order it represented (Osama Bin Laden, quoted in Bamber 2001). In both places the attacks caused a physical void to appear on the landscape.

Despite the difference in their contexts, the two sites of destruction implicate a number of similar issues, including: respect for or mitigation of the void; pre and post destruction narratives about the sites; the concept of loss; inscription and erasure of memory on a lived, monumental landscape; the concept of heritage applied to the site; perceptions of value; the politics and ethics of decision-making concerning the impacted terrain; assertions, contestations, and goals of stakeholdership; the aesthetics of reconstruction; the symbolism of reconstruction; the emotional and affective dimensions of reconstruction; economic development after destruction and its intended beneficiaries; what is considered recovery and by whom; the future that reconstruction is anticipated to generate; and formal interpretive scripts about the destruction and the physical form these scripts take. Bamiyan implicates other dimensions as well: authenticity, technology, cultural diplomacy, local social development, and war. Nevertheless, the many issues shared make New York City a worthwhile comparison for this volume about monument reconstruction in Bamiyan. In both cases there has been a tremendously complicated process concerning a built solution for the void that implicates geographically and emotionally proximal communities. In this chapter I focus on the people living close to the sites and most directly affected by the destruction wrought.

\section{Contesting Stakeholders}

9/11 was not just a human disaster, it was an infrastructural and financial disaster: for its technical owner, the Port Authority of New York and New Jersey; for Larry Silverstein, who had just obtained a 99-year lease to the WTC; and for the businesses that operated in the twin towers and nearby. In addition, 9/11 also implicated "those who possessed a different kind of claim on the site [and] they all viewed Ground Zero ${ }^{1}$ differently" (Sontag 2006). Two primary discourses thus came into conflict: redevelopment/rebuilding versus commemoration/remembrance. As Lynne Sagalyn put it, the WTC was "a contested site crowded with competing claims" (2016: 338).

\footnotetext{
${ }^{1}$ The area of impact immediately became known of Ground Zero, implicitly recalling the Trinity Test Site, Hiroshima and Nagasaki.
} 
The financial sector saw an opportunity to rebuild, redevelop and make huge profits from this property. This sector had tremendous power, know-how and the monetary and legal resources to exert their will (see Sorkin 2003; Goldberger 2005; Nobel 2005; Greenspan 2013; Sagalyn 2016). Only a month after the disaster The New York Times architecture critic Herbert Muschamp (2001a) had observed that "a wide cross-section of New York has been toiling to produce a plan for the redevelopment of the financial district."

On the other side and still reeling from their personal losses, as quickly the families of victims and survivors organized their own advocacy groups. We can think of the families as the local community that is a standard concern in contemporary principles of cultural heritage management. ${ }^{2}$ And, as is well documented in the heritage literature, communities and site managers often come into conflict. The Families Advisory Council, ${ }^{3}$ in particular, became a major voice speaking at and against power.

Decisions about what to do with the central area where the twin towers had stood were not exclusively top-down nor made completely behind closed doors, notwithstanding the real power-wielders. Family concerns were listened to by the Lower Manhattan Development Corporation ${ }^{4}$ and, to a degree, taken into account. ${ }^{5}$ A key requirement of the family groups was "to recognize the victims, to keep the footprints unencumbered, and provide access to the bedrock at Ground Zero" (Young 2006: 224). With the interests of the financial and infrastructural sectors allied against them, it is notable that the injured families were successful in preventing new commercial buildings from occupying the space where the towers had stood the 70-feet deep voids (the footprints) in which the fragmented or vaporized remains

\footnotetext{
${ }^{2}$ For instance, Article 8 of Nara Document on Authenticity (1994) states "Responsibility for cultural heritage and the management of it belongs, in the first place, to the cultural community that has generated it, and subsequently to that which cares for it"; Article 12 of the Burra Charter (1999) encourages "participation of people for whom the place has special associations and meanings..."; Paragraph 12 of the Operational Guidelines for Implementation of the World Heritage Convention encourages states parties "to ensure the participation of a wide variety of stakeholders, including site managers, local and regional governments, local communities, non-governmental organizations (NGOs) and other interested parties...."; and Paragraph 80 of the Operational Directives (2016) for implementation of the Intangible Cultural Heritage Convention (2003) states that participation of communities should be facilitated. The Journal of Community Archaeology and Heritage (established in 2014), arises out of this position and reflects the shift in heritage management from a technical and top-down practice to a bottom-up and co-creative approach (see, e.g., Harrington 1993; Watkins et al. 1995; McDavid 2002; Shackel and Chambers 2004; Little and Shackel 2007, 2014; Smith and Waterton 2009; Matthews 2011; Albert et al. 2012; Bollwerk and Connolly 2015).

${ }^{3}$ It was composed of "families of the victims, local residents and business people, and other groups affected by the attacks" (Young 2006:219).

${ }^{4}$ The Lower Manhattan Development Corporation was established in October 2001 to plan and coordinate redevelopment; many agencies were involved.

${ }^{5}$ Financial compensation for the families was egregiously low and the process was inhumanely conducted. A heart-wrenching letter from one family member on display in the museum indicates the pain suffered in the coldly administered bureaucratic process of compensation and the absurdly low amount of monetary value put on this father's life.
} 
of their loved ones lay. The families' success was due to what we might call community participatory action, notwithstanding its own internal disagreements (see, especially, Sagalyn 2016).

Importantly, the Families Advisory Council drafted the initial memorial mission statement and family members were part of the revision committee for that statement (Blais and Rasic 2011: 121). In addition, the memorial design jury received input by mail from over twenty victims' family organizations (Blais and Rasic 2011: 122). Thus, although the families were represented by only one member on the 13-person jury (see Young 2006: 221), they had had significant voice in shaping the requirements for the memorial competition. And once the eight finalists were chosen, the families again had the opportunity to comment (as did the public at a later showing) and the jury worked with the finalists to improve their designs (Blais and Rasic 2011: 129). Upon selection of Michael Arad's Reflecting Absence, the families were able to give more input through the Coalition of 9/11 Families and their ideas were largely accepted (Blais and Rasic 2011: 143). To a significant degree, then, the families got the memorial they wanted.

No solution to the extraordinarily complex situation of the 16 acres in lower Manhattan could have pleased everyone. But given the notoriously antagonistic relationship between New York City and New York State, and that developers and the principle of eminent domain had almost always been able to bulldoze (literally) citizen opposition, and that historic preservationists had lost many, many buildings, ${ }^{6}$ remarkably, over a tortuous 10 years, the 8 -acre core that had been occupied by the twin towers was preserved, memorialized (in 2011: see Blais and Rasic 2011) and interpreted (in 2014: see Greenwald 2016) in what was, realistically, I believe, a best-case scenario for the families, notwithstanding the criticism by some scholars (see, e.g. Low 2004; Rosenthal 2004) whose ideological and/or urban neighborhood expectations were unlikely to be fulfilled "where the rubber hits the road," as we say in America.

\section{Memory, Discourse and Dissonance at Ground Zero}

Ken Dornstein (1998) has written, "In the aftermath of death memory can become bound up with place, sites of loss can be sanctified, obliterated or physically marked." Adding an epilogue to their book as it went to press mere days after 9/11, Robert Nelson and Margaret Olin insightfully observed that instantaneously the WTC had "changed from a milieu de mémoire to a lieu de mémoire" (2003: 306). Indeed, the number of dead at the WTC and the horrible circumstances of their

\footnotetext{
${ }^{6}$ Historic preservationists made themselves heard as a discrete group, arguing for inscription of the site on the National Register of Historic Places. Also advocating were The New York Landmarks Conservancy, the Lower Manhattan Emergency Preservation Fund, the World Trade Center Survivors' Network, National Trust for Historic Preservation, and other groups. In a press release dated October 15, 2009 the National Trust for Historic Preservation noted the involvement of more than seventy consulting parties.
} 
death led rapidly to a public discourse about the site as sacred ground, a cemetery in effect (see, e.g. Murphy 2001). Marita Sturken perceptively suggested (2007: 205) that the footprints were imagined as giving the vanished dead a home where they could be visited, becoming, essentially, a burial ground without bodies (Aronson 2016). The tombstone nature of the memorial with its thousands of inscribed names serves as a place of personal mourning as well as being a place of public remembrance and commemoration (see Editorial 2001).

Although controversial when built and unloved before the attack, Michael J. Lewis (2001) observed that "In their absence the World Trade Center towers are more a monument than ever." He went on suggest that "The physical void they leave is itself a poignant memorial." The site of destruction, however, could not be left with a raw void. Rather, Michael Arad's memorial pools fill that space (but see Dunlap 2005), recalling the lives that once existed there and intending that emotional solace be physically embodied by the memorial.

Meaning, however, is another matter. Muschamp (2001b) presciently wrote days after the attack, "It will be months and years before the cultural meaning of the World Trade Center catastrophe comes into approximate focus." Nelson and Olin (2003: 306) correctly speculated that the future memorial would "further mold and focus social memory of the tragedy, in ways that [many] will debate." Writing yet 5 years later, James Young expressed the same opinion: "these events are not memory yet, but still unfolding before our eyes... Before we could remember the events of 9/11 we first had to know what they meant... Even now, 5 years later, we still don't really know what they meant entirely, which makes it difficult to fix in stone a particular memory" (2006: 214). Ground Zero was thus a made-to-order site of dissonance. $^{7}$

Multiple discourses by residents of lower Manhattan swirled in the months after the attack, as Setha Low (2004) and Joy Sather-Wagstaff (2011a) learned in their ethnographic fieldwork. Sather-Wagstaff, in particular, observed more complex social, emotional, performative, narrative, and political responses at the WTC than "negative" (Meskell 2002) - or in her critique - "dark" - would suggest. Yes, the

\footnotetext{
${ }^{7}$ Setha Low (2004) is correct that 9/11 generated a dominant, mass-mediated discourse and representation. "REBUILD. From the Ashes, The World Trade Center Rises Again" presents the widely shared dominant narrative of the site (https://www.youtube.com/watch?v=HzpyheliUcE; Accessed June 7, 2017). On site there has been little room for alternative views, whether of an urban or political nature. Dissonance is most obvious in the museum (see Aronson 2016; Gardner and Henry 2002; Greenwald 2010, 2016; Paliewicz 2017). Although some controversies are indicated, they are minimized in comparison to the scale of the dominant narratives of bravery, individual life and the triumph of human dignity, remembrance, commemoration, facticity, patriotism and resilience. The museum had to be profound, moving, inspirational, a witness to tragedy and an affirmation of freedom. The museum is more conceptually unstable than the memorial per se. Time has been a critical variable in the process of interpretation at Ground Zero as David Uzzell (2015) indicates with his clever phrase "the time of place." No museum exhibit is permanent, notwithstanding the phrase "permanent exhibition." 9/11 is on-going. Unlike Appomattox Court House, Armistice Day and VE Day marking definitive, victorious ends to wars, history with regard to Islamic jihadism has not concluded and the meaning and significance of 9/11 will continue to evolve. Eventually the museum will need to reinstall, amend, or add to the historical portion of the current script.
} 
devastated area was a "hole in the city's heart" (Sontag 2006), but heritage had not and has not yet inhered there (although it may in the future).

The WTC is not a cultural heritage site sensu strictu in the official discourse of the country, in the vernacular discourse of New Yorkers, in the official discourse of the National September 11 Memorial and Museum, or in the discourse of municipal agencies or the tourism industry - not immediately following the attack and not since then. Indeed, looking at December 7, 1941 at Pearl Harbor as the closest comparison, it is interesting to note that even three-quarters of a century later the term "heritage" is not used there, neither in vernacular or official discourse. Rather, the WTC is a new historic site within historic lower Manhattan. It is a site where an event of global magnitude happened and history continues to be made there. Thus, we are dealing with a category of "commemorative historical sites" (Sather-Wagstaff 2011a: 195), "public memory places" (Blair et al. 2010) and "places of pain" (Logan and Reeves 2009) whose dissonance (sensu Tunbridge and Ashworth 1996) pushes us to think about, reanalyze and debate the past while living and acting in the present and moving forward.

\section{Bamiyan: Why and for Whom to Reconstruct}

Lewis (2001), cited above, also recognized that the twin towers had "occupied a far greater position in the physical and psychological landscape of New York than anyone realized." I am influenced by Lewis as I think about Bamiyan, a place I have never visited. Although we know that the Buddhas in their carved stone niches were not the cherished ancestors of the Hazara people now living around them, ${ }^{8}$ certainly they were a familiar and defining feature of the landscape and, if pre-Taliban ethnography will bear this out, they were an element of place identity for that population. An American Rotarian who visited Bamiyan just before the destruction told me that local men described the Buddhas to him as "marvellous" but outside their Islamic tradition (personal communication, September 15, 2017). Matthew Power (2005) has accurately described the Hazara as presiding over a valley of ghosts - an expanding, militant Islam having forced Buddhists out of the region by the tenth century. Thus, although the Buddhas remained, "meaning faded with the years" (Power 2005: 71). But public discussion/efforts today about reconstruction of the Buddhas seeks to fix a meaning. If we return to Young's (2006) comment about the

\footnotetext{
${ }^{8}$ Dr. Masanori Nagaoka (personal communication, December 11, 2017) informs me that "It is not only the Hazara people who have resided in the Bamiyan Valley but Tajik people.... It was, in fact, mostly Tajik people who had lived there and were forced out by the Taliban. And it was Hazara who came back to Bamiyan city and took over Tajik lands. Unfortunately, most of the private and public land ownership information for Bamiyan, such as land use and land ownership documentation collected in the 1970s and 1980s was burned and/or lost during the more than three decades of armed conflict in Bamiyan." My argument about ethnic/cultural disconnect between the ancient Buddhist population and recent non-Buddhist population of Bamiyan is unaffected by the recent ethnic composition of Bamiyan: Hazara or Tajik.
} 
unresolved meaning of the 9/11 attack toward efforts at memorialization in New York, we can appreciate how very complicated the debate over what to do with the empty Bamiyan niches is in this unresolved, not post-conflict situation.

And whereas the affected 9/11 families clamored for commemoration but did not want the towers rebuilt, the question I have about Bamiyan is: do the Hazara want the Buddhas back and why, or is it the "international community" that wants to reconstruct the Buddhas because their destruction is an affront to the ideology and legitimacy of the global cultural order? Indeed, is this cultural heritage heritage for the Hazara?

It is important to understand that the 2003 World Heritage inscription does not include the giant Buddhas, which already had been blown up, but rather encompasses their niches in addition to seven other sites spread throughout the Bamiyan Valley. Moreover, the "cultural landscape and archaeological remains" in the listing title of the property are those of the long-gone Buddhist occupation making the disconnect with the centuries-old Muslim population ironic if not dissonant and highlighting the utilitarian nature of particular local as well as national calls for reconstruction.

Basically, the Afghan position at the Tokyo meeting seemed to express a desire to utilize a reconstructed Buddha(s) for tourism - an external motive - and as a visible rejection of the Taliban - an internal motive. Just as there were proposals to rebuild the twin towers on site at Ground Zero as an act of resistance to Al Qaeda, so, too, I would venture that local interest in the Buddhas - to the degree that this exists - is a reclamation of the landscape that the Taliban once occupied and on which they terribly mistreated locals (Zabriskie 2010). Indeed, "restoration is seen as a symbolic action pertaining to the identity of the nation and the valley" (ICOMOS Report 2014:13).

However, I question the ICOMOS Report's statement that "At both national and local level there is great enthusiasm for and strong expectations of the reconstruction of the two Giant Buddha statues" (2014: 13). The small local and national elite may be enthusiastic but do ordinary, impoverished inhabitants really care ${ }^{9}$ By way of comparison, in a recent (April 4, 2017) EuropeNow interview, Dacia Viejo-Rose, a noted scholar of heritage and conflict, observed, "The first loss that many Syrian refugees refer to when asked what they most miss of their culture and heritage, what they most mourn ... is not the arch at Palmyra that comes to mind but rather the traditional regular social gatherings amongst neighbours, friends, and family." Similarly, Michael Herzfeld cautions that "the remains of the past lie among living people for whom their significance may be far removed from that of academic research" (2012: 44) and that "Even the most imposing structures or historically significant sites that we most easily classify as monuments do not always mean the same thing to everyone" (ibid: 52). This must be the case for Bamiyan.

\footnotetext{
${ }^{9}$ The participants in the Tokyo meeting strongly recommended in the Recommendation resulting from this meeting that extensive consultation be conducted by the local and national governments in Afghanistan with the local communities of the Bamiyan Valley, with civil society, and with spiritual leaders so as to ensure that all stakeholder interests are taken into consideration.
} 
Power argues forcefully that there is a local utilitarian motivation for reconstruction: "the prospect of rebuilt sculptures attracting even a fraction of the town's former tourist bounty is extremely tempting" (2005: 73). But it is unrealistic to think that there will be tourism to Afghanistan. This is a country of terrorism and civil war, ${ }^{10}$ an unending, destabilizing American military intervention, government corruption, an illiteracy rate of $48 \%$ for men and $80 \%$ for women, mass poverty, an abusive, misogynist, patriarchal tribal society. I do not believe that the general Afghan population and, specifically, the local population are concerned with the Buddhas in the same way as the international community. And to offer the local people the promise or even possibility of tourism-generated economic development and stability around restored Buddhas is to ignore the miserable on-the-ground situation in Afghanistan.

I suspect that the Hazara have latched/will latch onto the Buddha reconstruction project as a vehicle for international attention, international development aid, and as a tool for positioning themselves better in the nation that has marginalized and abused them for generations (see, e.g., Hosseini 2003). I would not be surprised for a discourse of heritage ("our Buddhas") to emerge in Hazarajat, but it would not be "authentic", so to speak. It would be strategic, entrepreneurial, contrived. I am reminded of the day in January 2011 that I spent in the Pom Mahakan slum in the royal precinct of Bangkok where a community leader quoted Michael Herzfeld's defense of their occupancy to me, stating that they, the residents, were part of the intangible heritage of the district (see Herzfeld 2016). Similarly, several decades ago I heard highland squatters on the barren coastal hillsides south of Lima defend their tenancy based on a fictitious ancestral link with Pachacamac, the great archaeological site they border. An anonymous reviewer aptly read this paragraph as an example of "practical/tactical heritage."

I am interested, therefore, in which Hazara want reconstruction (see Kalman 2017: 544-545). Probably not the Hazara who are living in some of the Buddhist caves and are identified as a problem in the ICOMOS 2014 Report (compare to eviction of Petra's Bedouin). Probably, yes, those Hazara who are in a position to take advantage of international investment and tourism (whenever that may be). Escallon (2017) provides a relevant example of better situated members of a poor Afro-Colombian community who are able to exploit a UNESCO intangible cultural heritage designation and simultaneously how the designation has aggravated intracommunity tension. The ICOMOS Report refers to a Civil Society - "a group of representatives from the local community" (2014: 25) - that was consulted, among other stakeholders. I would venture that, similarly to Escallon's case, these are the Hazara who are best positioned to gain the most from participation with UNESCO. Certainly, the "National Geographic"-dressed Hazara woman "representing" that Civil Society at the Tokyo meeting was not representative of the female population of Hazara civil society nor of the majority of Afghan civil society.

\footnotetext{
${ }^{10}$ The last news from Kabul before I submitted this chapter was: "Twin Mosque Attacks Kill Scores in One of Afghanistan's Deadliest Weeks", reported by Jawad Sukhanyar and Mujib Mashal, The New York Times, October 20, 2017.
} 
I would hope that the noble ideals of reconstruction ${ }^{11}$ and its funding would include massive infrastructural and educational investment, capability training beyond heritage tourism for economic development, and gender behavioral intervention in a human rights framework to improve everyone's opportunity for a better life in Hazarajat. As Larry Coben, Executive Director of Sustainable Preservation Initiative, incisively says, "people cannot eat their history" (https://sustainablepreservationinitiative.wordpress.com/tag/lawrence-s-coben/). A dramatic, scenic ruinscape (Silverman 2016) occupied by photogenic, impoverished people (Denker 1985; Lutz and Collins 1993) should not be acceptable to the international community. The 2012 "Recommendation" arising from the 10th Expert Working Group Meeting on Bamiyan emphasized "the central importance of a cultural development approach in Bamiyan that incorporates and demonstrates the contribution of culture to sustainable livelihoods, education and the promotion of peace in Afghanistan." The unstated premises are that tourism is an economic motor and Western liberalism is a mindset that can be inserted and widely accepted in the region.

The 10th Expert Working Group Meeting also discussed "infrastructure and development plans of the Afghan Government for Bamiyan in the short and long term." This can happen without tourism and must be envisioned so as to initiate social and economic improvement in the valley. UNESCO's use of the word "safeguarding" for Bamiyan does not refer to protection of the valley's inhabitants from violence but, rather, stabilization of the niches, preservation of the fragments of the statues, protection of the mural paintings, removal of land mines throughout the World Heritage Site, and so forth. The destroyed Buddhas are a separate issue - for whether a restored or consolidated World Heritage Site will promote peace, tolerance, cultural diversity and a host of other stated ideals is debateable. What is obvious is that the people of Bamiyan will benefit greatly from comprehensive, well conceived development assistance - assuming it can be delivered in the current situation.

\section{Taking Bamiyan Out of the Past}

There is general agreement in the many "Recommendation" following the yearly UNESCO expert meetings about Bamiyan (held since 2002, the 13th was in 2016) that the larger, western niche should be consolidated and left empty as testimony to the destruction by the Taliban. At issue is the eastern niche of the smaller Buddha. The 2011 UNESCO document, "Ten years on - remembering the tragic destruction of the giant Buddha statues of Bamiyan (Afghanistan)", is explicit that "UNESCO

\footnotetext{
${ }^{11}$ The ideals of the reconstruction are best expressed in the mission statement of the associated cultural center: "encompassing the multi-layered heritage of Afghanistan's long history... build community around culture ... national unity to promote heritage safeguarding, cross-cultural awareness, and cultural identity thereby contributing to the broader aims of reconciliation, peacebuilding and economic development in Afghanistan" (Taylor-Foster 2015).
} 
does not favour rebuilding the Buddha statues." But the Afghan delegation at the 2017 Tokyo meeting emphatically called for, minimally, reconstruction of the eastern Buddha. The "Conclusions" negotiated at the end of the 2017 Tokyo meeting couch UNESCO's position in language that does not deny the request of the Afghans but puts conditions on approval for reconstruction that are unlikely to be met.

The Tokyo meeting was organized at the request of the Afghan government (expressed at the 40th World Heritage Committee meeting in Istanbul). UNESCO is not dictating to the Afghans what to do with the Buddhas and officially UNESCO does not have an opinion about reconstruction. Of course, the Afghans could decide to proceed on their own with rebuilding or creating a replica smaller Buddha - if this is within their technical ability. Such an act could provoke blowback from the larger international community concerned with strict reconstruction protocols. It is interesting to contemplate this counter-factual scenario and it is not without precedent. In 2011 Thailand almost denounced the World Heritage Convention over the World Heritage Committee's bias toward Cambodia concerning a contested World Heritage Site on the border of the two countries (Silverman 2011). And Oman and Germany each saw a World Heritage Site delisted by the World Heritage Committee when they did not comply with its demands.

Reconstruction (see discussion in Kalman 2017: 544-545) of the eastern Buddha would incorporate no more than $48 \%$ of the original fabric and does not include the face (presentation of ICOMOS Germany, Lehrstuhl für Restaurierung Kunsttechnologie und Konservierungswissenschaft Technische Universität München, September 27, 2017; also see ICOMOS 2014 Report). Aside from the issues of authenticity and integrity, I think that in this case reconstruction is passé. If we look to a better future in Hazarjat, I think we need a twenty-first century solution. Rather than consigning the Hazara to the landscape of ghosts by replacing the Buddhas, the destruction should be seen as an opportunity to move forward (see Holtorf 2006, 2015) with an expedient heritage integrated into a comprehensive regional development plan. This would open the way for the creation of new heritage rather than perpetuation of a landscape of mourning.

My preference is for a digital hologram (see Toubekis et al. 2010) - something akin to the "Tribute in Light" that projected two shafts of light upward in lower Manhattan (https://www.youtube.com/watch?v=pkWNVG_n2vs). Kalman (2017: 545 ) indicates that a laser light is already, temporarily, projecting three-dimensional holograms into the niches. A digital projection into the niches could present the Buddhas as they were just prior to their destruction alternating, perhaps, with a projection of their possible original appearance: Buddhas "gilded and decorated with lapis or perhaps ocher... arms were wooden armatures covered over with stucco and painted... the great alcoves in which they stood were painted with frescoes of the heavens... The colossi could have been adorned with sheets of reflective mica" (Power 2005: 71). "The Buddas once had an intensely colorful appearance" (Erwin Emmerling quoted by Becker 2011). This would be thrilling for tourists (in some unimaginable future - and surely more appealing than seeing fakes), visible for the Hazara (if they wish this in the first place), far less expensive to create, easy to replace if/when the Taliban return, and less international standards-challenging. 
Also, this projection proposal lies well within the range of son et lumiére shows at various World Heritage Sites.

Importantly, it would remember the void and the cause of absence: the Taliban's iconoclasm would be incorporated into the history of Bamiyan - presence in absence - rather than reconstructed over. Indeed, the winning proposal for the new cultural center in Bamiyan is called Descriptive Memory: The Eternal Presence of Absence. In one rendering architects Recabarren, Martínez and Morero dramatically taper a wall window to iterate and frame the void in the opposite cliff face (see: http://www.domusweb.it/content/domusweb/en/news/2015/03/19/bamiyan_cultural_centre_.html/). I am reminded of Bernard Tschumi's brilliant design of the New Acropolis Museum, which similarly looks out to the absent Parthenon marbles, making them present.

\section{Conclusion}

Joy Sather-Wagstaff has observed, "In the aftermath of a disaster, calls for the replacement, replication and reproduction of that which has been lost represent a yearning for a return to normal. Yet a full return to any pre-disaster 'normal' is impossible as the physical and emotional rupture of tragedy transforms everything and everybody. ... There is no unadulterated replacement, only re/placement" (2011b:5, italics in original). Re/placement has happened in New York. While the rebuilt area makes reference to the former site through the memorial, the overall 16 acres (the memorial and museum covering 8 acres plus the new buildings in the immediately surrounding area; Nobel 2005) are a palimpsest with stratified meanings - a place that enables the production of new memories, new senses of place and new identities.

Just a few years after 9/11, Setha Low (2004: 333) learned from her interviews with New Yorkers residing closest to Ground Zero that they did not want the memorialization of the site to put them in the position of living in a graveyard. That has not happened. Ground Zero is returning to being the WTC. Alongside memorialfocused tourism there is a vibrant domestic life and economy in the neighborhood. The physical transformation of Ground Zero has moved society and memory forward while keeping the past unavoidably within sight.

The memorial will always attest to the sacred quality of the site, hallowed by virtue of the human lives lost there, but mourning will eventually cease as the direct connection to victims (whether real or prosthetic) is broken by time. The surface level of this place of tragedy and trauma will become normalized in the same way that the grounds of the Oklahoma City National Memorial are again part of that city's urban fabric. Indeed, seen from ground level, the void at Ground Zero is emplaced in a pleasant tree-lined plaza that is public space in a densely built city. It permits both contemplation and enjoyment. Thus, in its realized form, and unanticipated by Low, the built memorial plaza actually has come very close to her own stated desire: "a complex space with gardens of reflection and recovery, buildings 
with memorials... as well as places to work and play, and open plazas for people to come together to discuss and disagree in a public environment ... a place to live again as well as to mourn and remember" (2004: 338). Following Young's distinction (2005), memory will become civic memory as personal memory recedes.

What will not change is the architectural configuration of the subterranean museum, which brilliantly incorporates and respects the site of destruction. The architecture of the museum contains the memorial's pools and has preserved sections of the towers' bedrock foundations, continuing Michael Arad's theme of reflecting absence and fulfilling one of the most passionately held demands of the families: "from infinity to bedrock." Museum and architecture are physically inseparable here: the in situ physical evidence of destruction has been made part of the interpretive script.

So, too, the winning architectural design for the cultural center in Bamiyan has made absence present. The voids can be a far more eloquent statement about the need for cultural tolerance, the importance of Hazarajat in the history of Afghanistan, and the global relevance of the (missing) Buddhas than an offense-mitigating reconstruction of the Buddhas.

I can envision Bamiyan and other sites of destruction - World Heritage Sites such as Palmyra, Aleppo, and Crac de Chevaliers and Tentative List sites such as Babylon and Nineveh - being linked in a serial inscription called "sites of cultural destruction." Rather than indulging in useless, enraged lamentations over loss and putting these places on UNESCO's List of World Heritage in Danger or some other such list (see Meskell 2002: 557), which accomplishes nothing on the ground, creation of this new serial inscription could serve as testimonial opposition to the scourge of violent cultural intolerance, with the ruins stabilized and interpreted in site museums (exceptional memorial architecture cum interpretive centers - each one well adapted to its particular cultural and geographical context) and being a fulcrum for heavy international agency and national government investment in the present of local people, not their past. In this sense, I am following Holtorf (2006, 2015) who argues that loss of a physical monument may be a natural part of the history of the environment, part of the continuous history of change, and may generate new identities and new heritage - although I do not see the obliteration of buildings/ monuments/sites in as positive a light as he does.

Local people may have formerly liked that which had deteriorated naturally over time, enjoyed looking at it, enjoyed visiting it, enjoyed intangible and tangible benefits from it. While reconstruction of a monument can be achieved technically, the more significant problem confronting outside specialists and local residents at a site of new physical destruction is to negotiate the stratified, consensual and conflicting meanings of that landscape. As architect Carol Burns (1991) has observed, every building site has historical contingency, intruding its past onto the proposed site of new construction. There is no such thing as a "cleared site." This is true in New York City and it is true in Bamiyan. The tremendously complicated process of enacting a built solution at Ground Zero can be a valuable lesson for Bamiyan and for new voids that will, unfortunately, come into existence in the future. 


\section{References}

Albert, M-T., Richon, M., Viñals, M.J., \& Witcomb, A. (Eds.). (2012). Community development through World Heritage (World Heritage Papers 31). Paris: UNESCO.

Aronson, J. D. (2016). Who owns the dead? The science and politics of death at Ground Zero. Cambridge: Harvard University Press.

Bamber, D. (2001, November 11). Bin Laden: Yes I did it. The Telegraph. http://www.telegraph. co.uk/news/worldnews/asia/afghanistan/1362113/Bin-Laden-Yes-I-did-it.html. Accessed 8 June 2017.

Becker, K. (2011). Bamiyan Buddhas once glowed in red, white and blue. http://www.eurekalert. org/pub_releases/2011-02/tum-bbo022511.php. Accessed 8 June 2017.

Blair, C., Dickinson, G., \& Ott, B. L. (Eds.). (2010). Places of public memory. Tuscaloosa: University of Alabama Press.

Blais, A., \& Rasic, L. (2011). A place of remembrance. Official book of the National September 11 Memorial. Washington, DC: National Geographic Society.

Bollwerk, E., \& Connolly, R., (Eds.). (2015). Advances in archaeological practice 3(3). Special issue: "Co-creation and public archaeology."

Burns, C. J. (1991). On site: Architectural preoccupations. In A. Kahn (Ed.), Drawing/building/ text: Essays in architectural theory (pp. 147-167). Princeton: Princeton Architectural Press.

Denker, D. (1985). Along Afghanistan's war-torn frontier. National Geographic, June: 772-797.

Dornstein, K. (1998). Where my brother fell to earth. A first visit to Lockerbie. The New Yorker, December 21: 44.

Dunlap, D. W. (2005, December 15). Memorial pools will not quite fill twin footprints. The New York Times. http://www.nytimes.com/2005/12/15/nyregion/memorial-pools-will-notquite-fill-twin-footprints.html?mcubz=1\&_r=0. Accessed 8 June 2017.

Editorial. (2001). In the body's place. The New York Times. October 19. http://www.nytimes. com/2001/10/19/opinion/in-the-body-s-place.html?mcubz=1. Accessed 29 May 2017.

Escallon, M. F. (2017). The formation of heritage elites: talking rights and practicing privileges in an Afro-Colombian community. In H. Silverman, E. Waterton, \& S. Watson (Eds.), Heritage in action. Making the past in the present (pp. 63-74). New York: Springer.

Gardner, J. B., \& Henry, S. M. (2002). September 11 and the mourning after: reflections on collecting and interpreting the history of tragedy. The Public Historian, 24(3), 37-52.

Goldberger, P. (2005). Up from zero. Politics, architecture and the rebuilding of New York. New York: Random House.

Greenspan, E. (2013). Battle for Ground Zero. Inside the political struggle to rebuild the World Trade Center. New York: St Martin's Press.

Greenwald, A. M. (2010). "Passion on all sides": lessons for planning the National September 11 Memorial Museum. Curator. The Museum Journal, 53(1), 117-125.

Greenwald, A. M. (2016). No day shall erase you. The story of $9 / 11$ as told at the National September 11 Memorial Museum. New York: Skira Rizzoli.

Harrington, S. P. M. (1993). New York's great cemetery imbroglio. Archaeology, March/ April: 30-38.

Herzfeld, M. (2012). Whose rights to which past? Archaeologists, anthropologists, and the ethics of heritage in the global hierarchy of value. In D. Shankland (Ed.), Archaeology and anthropology. Past, present and future (pp. 41-64). London: Berg.

Herzfeld, M. (2016). Siege of the spirits. Community and polity in Bangkok. Chicago: University of Chicago Press.

Holtorf, C. (2006). Can less be more? Heritage in the age of terrorism. Public Archaeology, 5, 101-109.

Holtorf, C. (2015). Averting loss aversion in cultural heritage. International Journal of Heritage Studies, 21(4), 405-421.

Hosseini, K. (2003). The kite runner. New York: Riverhead Books.

ICOMOS. (2014). Report on the ICOMOS advisory mission to cultural landscape and archaeological remains of the Bamiyan Valley (208rev). 26th to 31st May 2014. 
Kalman, H. (2017). Destruction, mitigation and reconciliation of cultural heritage. International Journal of Heritage Studies, 23(6), 538-555.

Lewis, M.J. (2001, September 16). In a changing skyline, a sudden, glaring wound. The New York Times. http://www.nytimes.com/2001/09/16/weekinreview/before-after-in-a-changing-skyline-a-sudden-glaring-void.html. Accessed 1 June 2017.

Little, B. J., \& Shackel, P. A. (Eds.). (2007). Archaeology as a tool of civic engagement. Lanham: AltaMira.

Little, B. J., \& Shackel, P. A. (2014). Archaeology, heritage and civic engagement. Working toward the public good. Walnut Creek: Left Coast Press.

Logan, W., \& Reeves, K. (2009). Places of pain and shame. Dealing with 'difficult heritage'. London: Routledge.

Low, S. (2004). The memorialization of September 11: Dominant and local discourses on the rebuilding of the World Trade Center site. American Ethnologist, 31(3), 326-339.

Lutz, C. A., \& Collins, J. L. (1993). Reading National Geographic. Chicago: University of Chicago Press.

Matthews, C. N., (Ed.). (2011). Archaeologies 7(3). Special issue: "Dynamics of inclusion in public archaeology."

McDavid, C. (2002). Archaeologies that hurt; descendants that matter. A pragmatic approach to collaboration in the public interpretation of African-American archaeology. World Archaeology, 34(2), 303-314.

Meskell, L. (2002). Negative heritage and past mastering in archaeology. Anthropological Quarterly, 75(3), 557-574.

Murphy, D. (2001, September 29). Slowly, families accept the ruins as burial ground. The New York Times, B1, B10.

Muschamp, H. (2001a, October 14). A rush to complete plans for downtown. The New York Times, p. 38.

Muschamp, H. (2001b, September 30). Filling the void: a chance to soar. The New York Times. http://www.nytimes.com/2001/09/30/arts/art-architecture-filling-the-void-a-chance-to-soar. html?mcubz=1. Accessed 2 June 2017.

Nelson, R. S., \& Olin, M. (2003). Monuments and memory, made and unmade. Chicago: University of Chicago Press.

Nobel, P. (2005). Sixteen acres. Architecture and the outrageous struggle for the future of Ground Zero. New York: Metropolitan Books.

Paliewicz, N. S. (2017). Bent but not broken: Remembering vulnerability and resilience at the National September 11 Memorial Museum. Southern Communication Journal, 82(1), 1-14.

Power, M. (2005). The lost Buddhas of Bamiyan. Harpers, March: 67-75.

Rosenthal, J. (2004). The future of Ground Zero. Daniel Libeskind's perverse vision. Policy Review, June/July: 3-16.

Sagalyn, L. (2016). Power at Ground Zero. Politics, money and the remaking of lower Manhattan. Oxford: Oxford University Press.

Sather-Wagstaff, J. (2011a). Heritage that hurts. Tourists in the memoryscapes of September 11. Walnut Creek: Left Coast Press.

Sather-Wagstaff, J. (2011b, September). Re/placing the World Trade Center. Anthropology News, p. 5.

Shackel, P., \& Chambers, E. (Eds.). (2004). Places in mind. Public archaeology as applied anthropology. New York: Routledge.

Silverman, H. (2011). Border wars: The ongoing temple dispute between Thailand and Cambodia and UNESCO's World Heritage List. International Journal of Heritage Studies, 17(1), 1-21.

Silverman, H. (2016). The ruinscape: UNESCO, the state, and the construction of identity and heritage in Phimai, Thailand. In A. Underhill \& L. Salazar (Eds.), Finding solutions for protecting and sharing archaeological heritage resources (pp. 33-53). New York: Springer.

Smith, L., \& Waterton, E. (2009). Heritage, communities and archaeology. London: Duckworth.

Sontag, D. (2006, September 11). Broken ground: the hole in the city's heart. The New York Times. http://www.nytimes.com/2006/09/11/world/americas/11iht-web.0911 groundzero.2762587. html?pagewanted=all\&mcubz=1. Accessed 30 May 2017. 
Sorkin, M. (2003). Starting from zero. Reconstructing downtown New York. New York: Routledge. Sturken, M. (2007). Tourists of history. Memory, kitsch, and consumerism from Oklahoma City to Ground Zero. Durham: Duke University Press.

Taylor-Foster, J. (2015). UNESCO reveals winning scheme for the Bamiyan cultural centre in Afghanistan. http://www.archdaily.com/600403/unesco-reveals-winning-scheme-for-thebamiyan-cultural-centre-in-afghanistan. February 19. Accessed 1 June 2017.

Toubekis, G., Mayer, I., Döring-Williams, M., Maeda, K., Yamauchi, K., Taniguchi, Y., Morimoto, S., Petzet, M., Jarke, M, \& Jansen, M. (2010). Preservation and management of the UNESCO World Heritage Site of Bamiyan: Laser scan documentation and virtual reconstruction of the destroyed Buddha figures and the archaeological remains. http://riegl.com/uploads/tx_pxpriegldownloads/185-2.pdf. Accessed 15 June 2017.

Tunbridge, J. E., \& Ashworth, G. J. (1996). Dissonant heritage. The management of the past as resource in conflict. Chichester: Wiley.

Uzzell, D. (2015). Postscript: The time of place. In M. L. S. Sorensen \& D. Viejo-Rose (Eds.), War and cultural heritage. Biographies of place (pp. 251-260). Cambridge: Cambridge University Press.

Watkins, J., Goldstein, L., Vitelli, K., \& Jenkins, L. (1995). Accountability: responsibilities of archaeologists to other interest groups. In M. J. Lynott \& A. Wylie (Eds.), Ethics in American archaeology. Challenges for the 1990s (pp. 33-37). Washington, DC: Society for American Archaeology.

Young, J. E. (2005). The memorial process: A juror's report from Ground Zero. In J. Mollenkopf (Ed.), Contentious City: The politics of recovery in New York City (pp. 140-162). New York: Russell Sage Foundation.

Young, J. E. (2006). The stages of memory at Ground Zero. In O. B. Stier \& J. S. Landers (Eds.), Religion, violence, memory, place (pp. 214-234). Bloomington: Indiana University Press.

Zabriskie, P. (2010). The outsiders. Set apart by geography and beliefs, oppressed by the Taliban, the Hazara people could be Afghtanistan's best hope. http://www.hazarapeople.com/2010/07/20/ hazaras-afghanistan-outsiders/. Accessed 6 June 2017.

The opinions expressed in this chapter are those of the author(s) and do not necessarily reflect the views of the UNESCO, its Board of Directors, or the countries they represent.

Open Access This chapter is licensed under the terms of the Creative Commons AttributionShareAlike 3.0 IGO License (https://creativecommons.org/licenses/by-sa/3.0/igo/), which permits use, sharing, adaptation, distribution, and reproduction in any medium or format, as long as you give appropriate credit to UNESCO, provide a link to the Creative Commons licence and indicate if changes were made. If you remix, transform, or build upon this chapter or a part thereof, you must distribute your contributions under the same licence as the original. This publication is also available at the UNESCO Open Access Repository: https://unesdoc.unesco.org/

The designations employed and the presentation of material throughout this publication do not imply the expression of any opinion whatsoever on the part of UNESCO concerning the legal status of any country, territory, city or area or of its authorities, or the delimitation of its frontiers or boundaries.

The authors are responsible for the choice and the presentation of the facts contained in this chapter and for the opinions expressed therein, which are not necessarily those of UNESCO and do not commit the Organization.

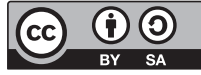

